4. Заярний О.А. Інформаційна сфера як об'єкт адміністративноправової охорони: деякі доктринальні та нормативні аспекти. Журнал східноєвропейського права. 2016. № 23. С. 18-31. URL: http://easternlaw.com.ua/wp-content/uploads/2016/01/zaiarnyi_23.pdf (Дата звернення: 26.10.2020).

5. Договір приєднання про надання послуг з пошуку вразливостей Електронної системи закупівель Громадського об’єднання «РЕСКІЛЛ». URL: https://docs.google.com/document/d/1LKfr6em6ishurqug42kdq4VaIt8RrZ6/edit (Дата звернення: 26.10.2020).

6. Договір № 00000306/Г з надання послуг щодо реалізації проекту «Electronic Procurement System Bug Bounty Program». URL: https://www.dzo.com.ua/tenders/7036537 (Дата звернення: 26.10.2020).

7. HACKERONE FINDER TERMS AND CONDITIONS Effective Date: June 1, 2020. Url: https://www.hackerone.com/terms/finder (Дата звернення: 26.10.2020).

DOI https://doi.org/10.30525/978-9934-588-92-1-65

\title{
ON THE ISSUE OF GRANTING CONCENTRATION PERMISSIONS TO BUSINESS ENTITIES UNDER THE LAWS OF UKRAINE
}

\author{
Pasichnyk V. V. \\ Attorney at law, \\ Graduate Student \\ Informatics and Law Research Institute of the National Academy \\ of Legal Sciences of Ukraine \\ Kyiv, Ukraine
}

In order to preclude monopolization of commodity markets, abuse of monopoly (market) power, restriction on competition and prevention of unfair competition in Ukraine, the legislator enshrined the obligation of business entities to apply to the Antimonopoly Committee of Ukraine for concentration permission, in particular, for direct or indirect procurement, acquisition of ownership in other way or receipt of equity (stocks and shares) in trust which ensures the achievement or excess of 25 or 50 percent of the votes in the supreme management body of the business entity.

The issue of obtaining permission of the Antimonopoly Committee of Ukraine for concentration, i.e. for acquisition by a business entity of a 
portfolio of state-owned shares in the authorized capital of companies which constitute over than 50 percentage of votes in the supreme management body of the business entity which is being acquired through privatization procedure brings to notice the following.

Pursuant to Art. 20(1) of the Law of Ukraine «On Privatization of State and Municipal Property» in cases specified by the laws on protection of economic competition, the purchaser shall obtain permission of the Antimonopoly Committee of Ukraine for direct or indirect acquisition of shares (equity) which amount to or exceed 25 or 50 percent of the votes in the supreme management body of the relevant business entity, as well as assets in the form of a single property complex or structural division of the business entity [1]. The cases when the economic entities are required to obtain the concentration permission are defined in Art. 24 of the Law of Ukraine «On the Protection of Economic Competition» and paragraph 1 of chapter V «Obtaining permissions and findings» of the Regulations on the Procedure for Submission and Processing of Applications for Prior Permission by the Antimonopoly Committee of Ukraine of Concentration of Business Entities, approved by the Resolution of the Antimonopoly Committee of Ukraine of 19.02.2002 No. 33-r (hereinafter - the Regulations on Concentration).

Article 26(5) of the Law of Ukraine «On the Protection of Economic Competition» and paragraph 5 of section VII «Procedure for Filing of an Application» of the Regulations on Concentration stipulate that if concerted actions or concentration is carried out with the use of competition procedures (tenders, auctions, competitions, etc.), an application may be submitted both before and after the competition procedure within a period of 30 days from the date of the winner being awarded the victory unless laws provide for otherwise $[2 ; 3]$. Therefore, the legislator gave business entities participating in the concentration the opportunity to apply to the Antimonopoly Committee of Ukraine for the permission to concentrate both before and after the tender procedure.

In our opinion, formalisation of the opportunity to submit an application for concentration to the Antimonopoly Committee of Ukraine before the competition procedure and within a period of 30 days from the date of the winner being awarded the victory, is inappropriate based on the following:

1. Regarding the submission of an application for obtaining a concentration permission before the competition procedure.

The Law of Ukraine «On Privatization of State and Municipal Property» defines auction as a method of sale of the privatization object with the buyer who offered the highest price for the privatization object during the auction becoming the owner of it [1]. That is, if several potential buyers participate 266 
in the auction pursuing acquisition of the ownership of the state-owned portfolio of shares in the authorized capital of a joint stock company and achieve more than 50 percent of votes in the supreme management body of such a joint stock company, the purchaser of small-scale privatization object would be one purchaser - the winner, who offered the highest price for such an object during the auction.

Based on Art. 26(5) of the Law of Ukraine «On the Protection of Economic Competition» and paragraph 5 of Section VII «Procedure for Filing of an Application» of the Regulations on Concentration, such a business entity is entitled to file before the auction a joint application on obtaining concentration permission with the business entity which shares it pursues to purchase through privatisation.

In our opinion, there is no reason to file the application to the Antimonopoly Committee of Ukraine for concentration permission before such competition procedure as auction, as far as it is unknown whether such a potential purchaser - business entity will win the auction and execute a contract of sale with the privatization body.

2. Regarding the submission of an application for concentration permission after the competition procedure, but within thirty days from the date of the winner being awarded the victory.

Since the winner of the auction is a business entity that offered the highest price for the small-scale privatization object during the auction, as it proceeds from Art. 26(5) of the Law of Ukraine «On the Protection of Economic Competition» and paragraph 5 of Section VII «Procedure for Filing of an Application» of the Regulations on Concentration, in the cases specified in Art. 24 of the Law of Ukraine «On the Protection of Economic Competition» and paragraph 1 of Section V «Obtaining permissions and findings» of the Regulations on Concentration, such a winner (purchaser) is obliged to file an application to the Antimonopoly Committee of Ukraine together with the joint stock company, the shares of which it acquires, for the acquisition of a portfolio of shares in a company, which constitute more than 50 percent of the votes in the supreme management body of such a joint stock company, within a period of 30 days from the date of announcing him as a winner.

We consider the statutory obligation of the purchaser to file the application to the Antimonopoly Committee of Ukraine for a concentration permission within the period of thirty days from the date of announcement of the winner inexpedient, as far as following the auction results the privatization body for the sale of the small-scale privatization object may decide on refusal to approve the record of electronic auction or on refusal to execute a contract of sale with such a winner. The privatization body may 
render such a decisions after verifying the application for participation in the privatization of a small-scale privatization object together with the documents attached to it and the information of the auction winner. The grounds for making such decisions may be as follows: winner's noncompliance with the requirements to buyers of privatization objects; failure of the winner of the competition to submit documents or information, if such submission was mandatory under the law; submission of false information about his identity by the winner of the competition.

Thus, we may point out that on September 10, 2020 the Antimonopoly Committee of Ukraine adopted a decision No. 578-r on granting a concentration permission, which is the acquisition of shares of the «Hotel Dnipro» Private Joint-Stock Company (Kyiv, identification code of legal entity 02573547), by the «Smartland» Limited Liability Company (Brovary, Kyiv region, identification code of legal entity 38767326) which affords exceeding of 50 percent of the votes in the supreme management body of the company. As this decision indicates, «Smartland» Limited Liability Company won the electronic competition for the sale of the state portfolio of shares of the «Hotel Dnipro» Private Joint-Stock Company (record of the electronic auction No. UA-PS-2020-06-14-000010-3, approved by the order of the State Property Fund of Ukraine dated July 29, 2020 No. 1268).

In view of the aforesaid, we consider it appropriate to amend the Law of Ukraine «On the Protection of Economic Competition» and the Regulations on Concentration by requiring from the winner of the competition to apply to the Antimonopoly Committee of Ukraine for concentration permission, in particular, to acquire portfolio of shares in business entity which affords exceeding 50 percent of votes in the supreme management body of such a joint-stock company, if such permission is required by law, only following the verification of the application for the participation in privatization of the small-scale privatization object together with the documents and information of the auction winner attached, approval of the record of electronic auction and execution of contract of sale with such winner by the privatization body. That is, from the moment of execution and signing of a contract of sale with the privatization body, the purchaser - business entity shall be obliged to obtain a concentration permission of the Antimonopoly Committee of Ukraine, if obtaining of such permission is required by law. In our opinion, such amendments to the competition legislation of Ukraine in force will improve the legislative support of the procedure for application of the purchaser - business entity for concentration permission of the Antimonopoly Committee of Ukraine, conducted under a competitive procedure (auction). 


\title{
References:
}

1. Про приватизацію державного та комунального майна : Закон України від 18 січня 2018 р. № 2269-VIII. Відомості Верховної Ради України. 2018. № 12. Ст. 68. URL: https://zakon.rada.gov.ua/laws/show/ 2269-19 (дата звернення: 26.10.2020).

2. Про захист економічної конкуренції : Закон України від 11 січня 2001 p. № 2210-III. Відомості Верховної Ради Украӥни. 2001. № 12. Ст. 64. URL: https://zakon.rada.gov.ua/laws/show/2210-14 (дата звернення: 26.10.2020).

3. Положення про порядок подання та розгляду заяв про попереднє отримання дозволу Антимонопольного комітету України на концентрацію суб'єктів господарювання : затв. розпорядженням Антимонопольного комітету України від 19 лютого 2002 р. № 33-p. URL: https://zakon.rada.gov.ua/laws/show/z0284-02 (дата звернення: 26.10.2020).

DOI https://doi.org/10.30525/978-9934-588-92-1-66

\section{НЕКОТОРЫЕ ПРОБЛЕМЫ ЗАЩИТЫ ПРАВ ПОТРЕБИТЕЛЕЙ ДИСТАНЦИОННЫХ БАНКОВСКИХ УСЛУГ}

\author{
Плотникова М. В. \\ кандидат юридических наук, \\ дочент кафедры международного, \\ европейского права и гражданско-правовых дисииплин \\ Сумского государственного университета \\ 2. Сумы, Украина
}

Деятельность по оказанию банковских услуг, как и других финансовых услуг, детально урегулирована правовыми нормами с целью защиты потребителей как менее защищенную сторону правоотношений. Законами Украины «О банках и банковской деятельности», «O платежных системах и переводе средств в Украине», «О финансовых услугах и государственном регулировании финансовых услуг» определены понятие банковских услуг и основные требования к субъектам, которые имеют право их оказывать. Подзаконное регулирование данной сферы осуществляется нормативно-правовыми актами Национального банка Украины. 